\title{
Runoff and soil and nutrient losses in semiarid uncultivated fields ${ }^{1}$
}

\author{
Escoamento, perdas de solo e nutrientes em campos não cultivados em regiões \\ semiáridas
}

\author{
Julio Cesar Neves dos Santos ${ }^{2 *}$, Helba Araújo de Queiroz Palácio ${ }^{3}$, Eunice Maia de Andrade ${ }^{4}$, Ana Célia Maia \\ Meireles $^{4}$ e José Ribeiro de Araújo Neto ${ }^{5}$
}

\begin{abstract}
Although water erosion is the principle agent responsible for soil degradation, field data on the impacts of erosion, due to high operational costs and measurement difficulties, are scarce, especially in semiarid regions. In this context, the aim of this study was to evaluate runoff and soil and nutrient losses in uncultivated areas in the semiarid region of the state of Ceará in Brazil. The experiment was conducted in a $20 \mathrm{~m}^{2}$ erosion plot that was uncultivated and populated with herbaceous plants. Data were collected during the rainy season from January to May 2009. Monthly water losses from overland flow ranged from 3.4 to $168.9 \mathrm{~mm}$, representing 1.8 to $42.3 \%$ of the total monthly rainfall for January and April, respectively. Soil loss from erosion totaled 2,166.6 $\mathrm{kg} \mathrm{ha}^{-1}$. In February, soil losses were $834.3 \mathrm{~kg} \mathrm{ha}^{-1}$, corresponding to $38.5 \%$ of the total value. The rainfall erosivity index $\left(\mathrm{EI}_{30}\right)$ was $5,716.4 \mathrm{MJ} \mathrm{mm} \mathrm{ha}^{-1} \mathrm{~h}^{-1}$. The observed high variability of soil losses in individual events was influenced mainly by the antecedent soil water content. Although this study used only one year of observations, the findings are important for land use planning, especially in the semiarid region of Brazil, where datasets are scarce.
\end{abstract}

Key words - Soil-erosion. Sediments (Geology). Arid regions.

\begin{abstract}
Resumo - Embora a erosão hídrica seja a principal agente no empobrecimento dos solos e na contaminação dos recursos hídricos, poucos são as mensurações efetuadas em campo. A baixa disponibilidade de dados obtidos in loco é decorrente do elevado custo e das dificuldades na efetivação destas mensurações, em especial nas regiões semiáridas. Neste sentido, o presente estudo teve como objetivos investigar a ação das erosividades das chuvas sobre o escoamento superficial, bem como as perdas de solo e nutrientes em áreas não cultivadas do semiárido cearense. O experimento foi conduzido em uma parcela de erosão $\left(20 \mathrm{~m}^{2}\right)$ sob condições de áreas não cultivadas com cobertura vegetal composta por extrato herbáceo. Neste estudo foram investigados 37 eventos registrados no período chuvoso de 2009 (janeiro/maio). O acumulado mensal do escoamento superficial variou de 3,4 a 168,9 mm, correspondendo a 1,8 e 42,3\% da precipitação total mensal, para janeiro e abril, respectivamente. As perdas de solo para todo o período estudado foram de 2.166,6 $\mathrm{kg} \mathrm{ha}^{-1}$, com destaque para o mês de fevereiro com perdas de $834,3 \mathrm{~kg} \mathrm{ha}^{-1}$, correspondendo a 38,5\% do valor total. O índice de erosividade $\left(\mathrm{EI}_{30}\right.$ ) da chuva foi de 5.716,4 $\mathrm{MJ} \mathrm{mm} \mathrm{ha}^{-1} \mathrm{~h}^{-1}$. A alta variabilidade nos valores de perda de solo por eventos isolados foi influenciada principalmente pela umidade antecedente do solo. Os resultados obtidos nesse trabalho, embora iniciais, são valiosos para a gestão e planejamento adequado de uso da terra, principalmente em regiões semiáridas onde essas informações são mais escassas.
\end{abstract}

Palavras-chave - Solos-erosão. Sedimentos (Geologia). Regiões áridas.

\footnotetext{
* Autor para correspondência

${ }^{1}$ Recebido para publicação em 30/08/2010; aprovado em 13/05/2011

Parte da monografia do primeiro autor

${ }^{2}$ Programa de Pós-Graduação em Engenharia Agrícola, Centro de Ciências Agrárias/UFC, Fortaleza-CE, Brasil, juliocesarnds@yahoo.com.br ${ }^{3}$ Instituto Federal do Ceara, Campus de Iguatu-CE, Brasil, helbaraujo23@yahoo.com.br

${ }_{4}^{4}$ Departamento de Engenharia Agrícola, CCA/UFC, Fortaleza-CE, Brasil, eandrade@pq.cnpq.br, ameireles2003@yahoo.com.br

${ }^{5}$ Programa de Pós-Graduação em Engenharia Agrícola, Centro de Ciências Agrárias/UFC, Fortaleza-CE, Brasil, junior.bg@bol.br
} 


\section{Introduction}

Soil erosion is one of the most challenging global environmental problems. The United States maintains the largest dataset on soil erosion, which uses a patterned methodology. In Europe, erosion data comes from a series of research projects based on different methodologies, and only a portion of them used experimental erosion field plots under conditions similar to those used in the United States (CERDAN et al., 2010). These datasets contain important information on actual erosion rates. Soil erosion investigations are typically conducted in experimental plots with different characteristics. Variations in scale and differences in the factors investigated can determine the quality of the erosion dataset. Studies using different plot sizes can help to identify natural variability (BAGARELLO; FERRO, 2004; BOIX-FAYOS et al., 2007).

Land use plays an important role in the control of the erosion process (AGUIAR et al., 2006; DASS et al., 2011; SANTOS et al., 2000). Removing vegetation can significantly reduce water infiltration rates and increase surface runoff and erosion. Although soil erosion results in the loss of soil fertility, land degradation and water pollution, the amount of information on erosion under field conditions is limited. Researchers from different parts of Brazil have commented on the scarcity of data in related to erosion (ALBUQUERQUE et al., 2002; BERTOL et al., 2004; FRANCO et al., 2002; SANTOS, 2009).

Among the major factors influencing soil erosion, rainfall erosivity is difficult to predict and control (MARTINS et al., 2003). Accurate estimation of rainfall erosivity requires continuous rainfall data, which is rarely of acceptable spatial and temporal coverage. This limitation is as defined by best land use management practices (ANGULO-MARTÍNEZ; BEGUERÍA, 2009). Rainfall intensity is major component related to soil erosion and sediment yield (MELLO et al., 2003; RODRIGUES, 2009).

Northeast Brazil is the most populated semiarid region in the world, with a population of 51,534,406 habitants (IBGE, 2010). In this area, large quantities of agricultural and forest products are consumed, and to meet demands, vegetation is harvested from the Caatinga Forest without the observation of best management practices, resulting in soil degradation by erosion (ALBUQUERQUE et al., 2002; INÁCIO et al., 2005). Additionally, the effects of rainfall intensity (erosivity process) on erosion in the semiarid region of Brazil have not received sufficient attention. Investigations of long-term flow and erosion processes were initiated in small watersheds in the semiarid region of Brazil, but they were interrupted after a short period of data collection because of high operational costs.
(SANTOS et al., 2007). An understanding of the erosion process in this region requires an evaluation of runoff and losses of water, soil and nutrients in undisturbed soils.

\section{Materials and methods}

This study was performed in the Alto Jaguaribe watershed, located between $6^{\circ} 23^{\prime} 38^{\prime \prime}$ and $6^{\circ} 23^{\prime} 58^{\prime \prime} \mathrm{S}$ and $39^{\circ} 15^{\prime} 21^{\prime \prime}$ and $39^{\circ} 15^{\prime} 38^{\prime \prime} \mathrm{W}$ at an elevation of $217 \mathrm{~m}$ (FIG. 1). The field plot experiment was conducted in the experimental watershed of the Instituto Federal de Educação, Ciência e Tecnologia do Ceará (IFCE), Campus de Iguatu, in Iguatu County, Ceará, Brazil. The experimental plot was monitored during the wet season (January to May) of 2009. The climate in the region is semiarid, with a mean air temperature of $29^{\circ} \mathrm{C}$. Average annual precipitation is $970 \mathrm{~mm}$, and rainfall events are often characterized by short durations and high intensities. Nearly $80 \%$ of the total precipitation falls during the summer and fall (January to May). The soils in the area are predominantly Vertisols Ebonics Carbonates, according to Embrapa (1999). The physical and chemical properties of the soil in the field plots are shown in Table 1. The cover vegetation in the experimental plot was mostly grass (Axonopus purpuni) and bush (Hyptis sauaviolens) species. At the end of the wet season, the soil surface is $100 \%$ covered.

The runoff and soil and nutrient losses were measured in a plot that was $2 \mathrm{~m}$ wide and $10 \mathrm{~m}$ long $\left(20 \mathrm{~m}^{2}\right)$ and located on a fallow slope (FRANCO et al., 2002). The average slope of the experimental plot was $9.8 \%$. The plot was bounded on all sides by galvanized iron (GI) CHAPA that was buried to a depth of $0.15 \mathrm{~m}$ to prevent outside influences (FIG. 2). The lower end of the plot was connected to a collector system composed of three galvanized iron tanks with volumes of $30 ; 100$ and $200 \mathrm{~L}$. The first is a multi-slot tank with seven slots. The spout of the first tank was connected to the second and third tanks.

A total of 72 rainfall events were registered, 37 of which produced runoff and sediment yield. Runoff from the experimental plot was recorded daily by measuring the depth of water collected in the runoff collection tanks. To determine soil and nutrient losses, runoff samples were taken from the tanks after agitation in 1-liter bottles. Samples were sent to the Soil and Water Laboratory of the Instituto Federal de Educação, Ciência e Tecnologia do Ceará (IFCE), Campus Iguatu, to quantify the total solids and the amounts of $\mathrm{Ca}, \mathrm{Na}, \mathrm{Mg}, \mathrm{SO}, \mathrm{K}$ and $\mathrm{PO}$, according to the APHA (1998) methodology. Runoff depth was 
Table 1 - Soil physical and chemical properties of the field plot

\begin{tabular}{cccccccccc}
\hline \multicolumn{2}{c}{ Particle size distribution (\%) } & Global density & O.M. & $\mathrm{P}$ & $\mathrm{K}_{\text {sat }}$ & $\mathrm{C} / \mathrm{N}$ & $\mathrm{EC}$ & $\mathrm{pH}$ \\
\hline Clay $<0.002$ & Silt $0.002-0.05$ & Sand $>0.05$ & $\left(\mathrm{~g} \mathrm{~cm}^{-3}\right)$ & & $\left(\mathrm{g} \mathrm{kg}^{-1}\right)$ & $\left(\mathrm{mm} \mathrm{h}^{-1}\right)$ & & $\mathrm{dS} \mathrm{m} \mathrm{m}^{-1}$ \\
\hline 11 & 46 & 43 & 1.22 & 2.03 & 1.22 & 5.10 & 10 & 0.18 & 6.8 \\
\hline
\end{tabular}
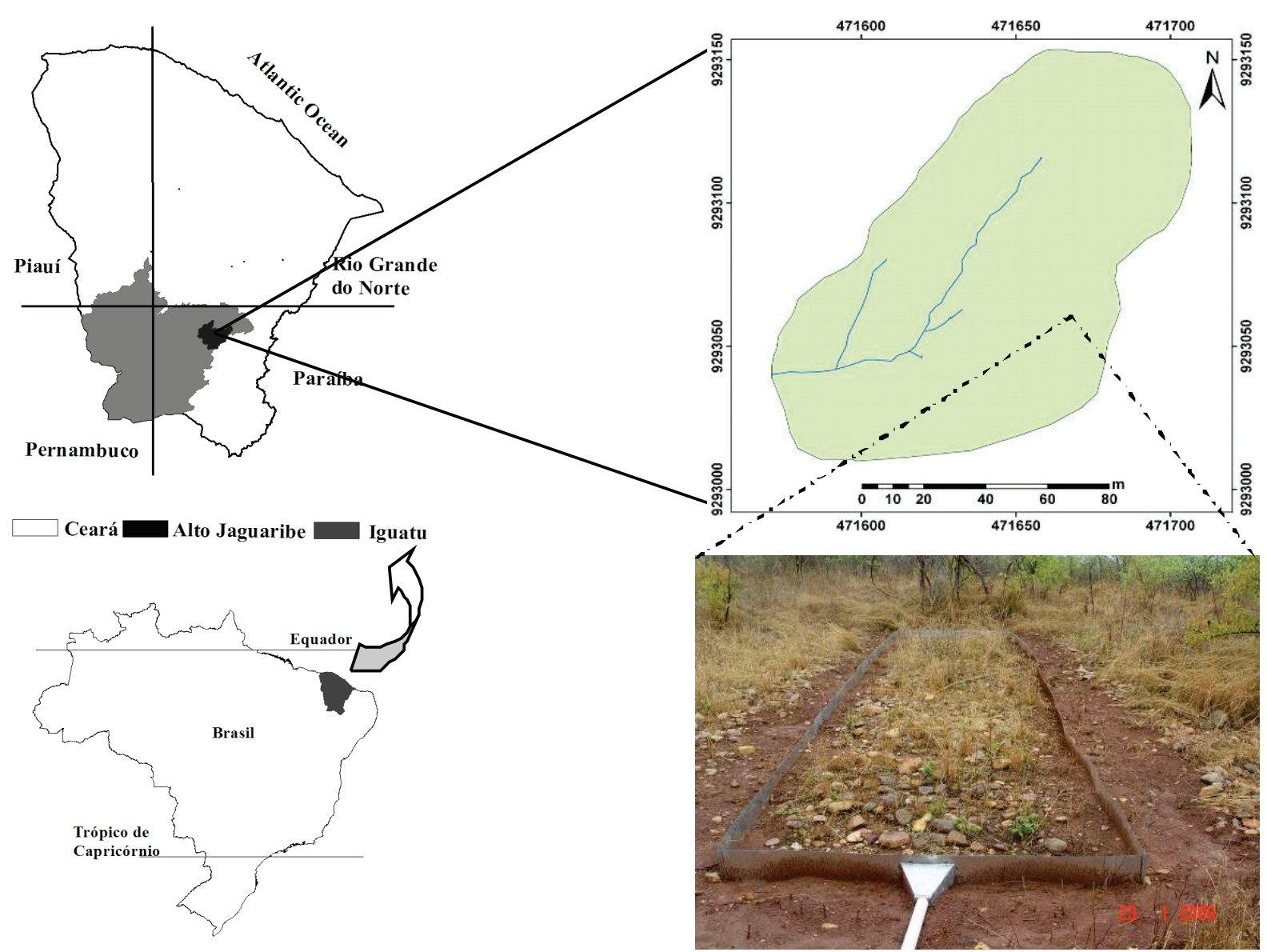

Figure 1 - Location of the study area in the Alto Jaguaribe watershed, Ceará, Brazil

estimated as a function of the total drainage volume and the plot area, and the soil and nutrient losses were estimated as functions of the total solids and nutrients concentrations in the sampled water.

The rainfall dataset was collected from a rain gauge in the experimental watershed, which recorded values every five minutes. From the daily rainfall dataset, the intensity of events (I) in $\mathrm{mm} \mathrm{h}^{-1}$ and the maximum 30 -min intensity $\left(\mathrm{I}_{30}\right)$ in $\mathrm{mm} \mathrm{h}^{-1}$ were calculated. The kinetic energy (E) associated with the rainfall in $\mathrm{MJ} \mathrm{ha} \mathrm{hm}^{-1} \mathrm{~mm}^{-1}$ was calculated from Equation
1 (WISCHMEIER; SMITH, 1978) and modified according to Foster et al. (1981).

$$
\mathrm{E}=0.119+0.0873 \log \mathrm{I}
$$

where $\mathrm{E}$ is the total storm energy $\left(\mathrm{MJ} \mathrm{ha}^{-1} \mathrm{~mm}^{-1}\right)$, and $\mathrm{I}$ is the rainfall intensity $\left(\mathrm{mm} \mathrm{h}^{-1}\right)$.

The values obtained from Equation 1 were used to calculate the rainfall erosivity index for storms $\left(\mathrm{EI}_{30}\right)$, which is proportional to the product of the total storm energy (E) and the maximum 30-min intensity $\left(\mathrm{I}_{30}\right)$. 


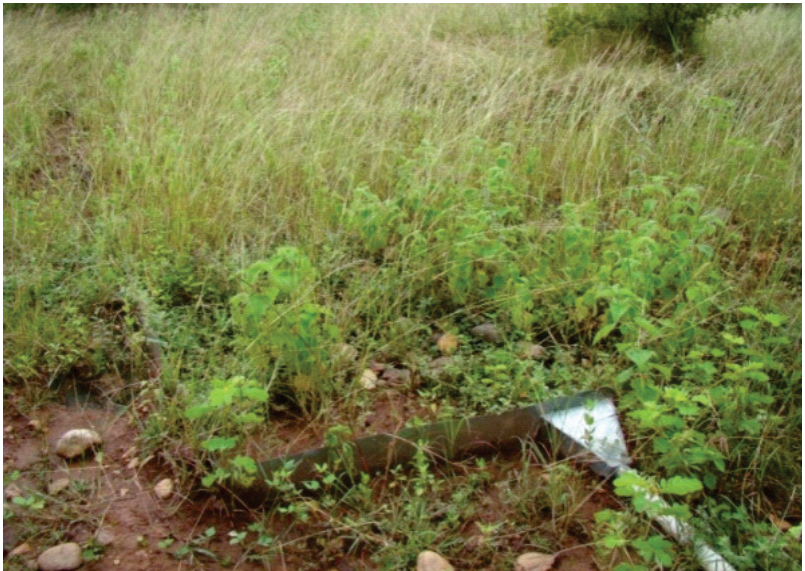

Figure 2 - The experimental plot and the multi-slot tank

\section{Results and discussion}

The total monthly depth of runoff was $332.3 \mathrm{~mm}$ (TAB. 1), representing $31.3 \%$ of the total rainfall depth. Although the total rainfall depth $(1,062.6 \mathrm{~mm})$ during the studied period was $26.4 \%$ greater than the region average, the total depth of runoff was not different from the annual average runoff for the region (SANTOS et al., 2007). Thus, a larger amount of rainfall (depth) did not necessarily indicate a greater runoff depth; rather, runoff depth was more dependent of rainfall intensity.

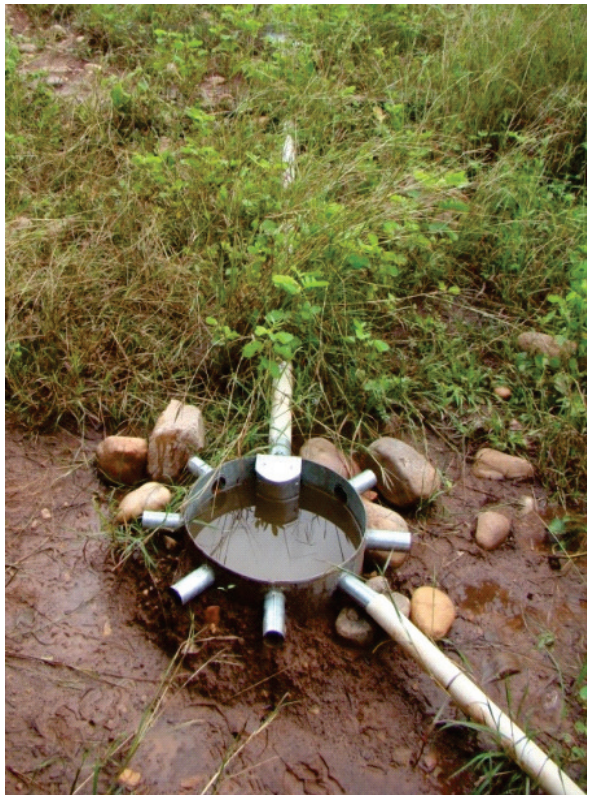

The percentage of rainfall that became surface runoff was highly variable, ranging from 1.8 to $43.9 \%$ from January to May 2009, respectively. In January, which is the beginning of the wet season, the soil was dry and the rate of infiltration was high. In May, when the soil moisture content was high and rainfall events occurred over consecutive days, surface runoff represented $43.9 \%$ of total rainfall. The high variability in monthly surface runoff percentages could be related to antecedent soil moisture conditions (BOIX-FAYOS et al., 2007; MELLO et al., 2003).

Table 1 - Monthly rainfall, runoff depth, soil loss and erosivity measured in the field

\begin{tabular}{|c|c|c|c|c|c|}
\hline \multirow{3}{*}{ Month } & \multicolumn{5}{|c|}{2009} \\
\hline & \multirow{2}{*}{$\frac{\text { Rainfall }}{(\mathrm{mm})}$} & \multicolumn{2}{|c|}{--------------Runoff depth------------- } & \multirow{2}{*}{$\frac{\text { Soil loss }}{\left(\mathrm{kg} \mathrm{ha}^{-1}\right)}$} & \multirow{2}{*}{$\frac{\mathrm{EI}_{30}}{\left(\mathrm{MJ} \mathrm{mm} \mathrm{ha} \mathrm{m}^{-1} \mathrm{~h}^{-1}\right)}$} \\
\hline & & $(\mathrm{mm})$ & $(\%)$ & & \\
\hline January & 193.3 & $3.4 *$ & $1.8^{*}$ & $170.3 *$ & $182.2 *$ \\
\hline February & 217.7 & 77.8 & 35.7 & 834.3 & 1837.0 \\
\hline March & 134.4 & 30.4 & 22.6 & 289.6 & 470.5 \\
\hline April & 398.9 & 168.9 & 42.3 & 745.2 & 2723.8 \\
\hline May & 118.3 & 51.9 & 43.9 & 127.2 & 502.8 \\
\hline Total & 1062.6 & 332.4 & 31.3 & 2166.6 & 5716.4 \\
\hline Standard deviation & 111.9 & 63.5 & 17.5 & 332.3 & 1091.5 \\
\hline $\mathrm{CV} \%$ & 52.7 & 95.5 & 59.8 & 76.7 & 95.5 \\
\hline
\end{tabular}

* Two events were not recorded (January $30^{\text {th }}$ and $31^{\text {st }}$ events with 76.5 and $11.9 \mathrm{~mm}$ of runoff, respectively) 
The highest soil loss was observed in February (TAB. 1) when vegetation had not yet fully developed. In this region, the wet season begins in January or February after a long dry season (from June to December). In February, the soil is not yet protected by vegetation. The $\mathrm{EI}_{30}$ in February $\left(1,837.0 \mathrm{MJ} \mathrm{mm} \mathrm{ha}^{-1} \mathrm{~h}^{-1}\right)$ was the second highest index registered. Although, the highest rainfall depth, $\mathrm{EI}_{30}$ and runoff depth occurred in April, soil loss in this month was lower than that recorded in February. This could be explained by protection from the well-developed vegetation against the direct action of rainfall erosivity (DASS et al., 2011; INÁCIO et al., 2005).

The annual erosivity and total soil loss for the study period were $5716.4 \mathrm{MJ} \mathrm{mm} \mathrm{ha}^{-1} \mathrm{~h}^{-1}$ and $2166.6 \mathrm{~kg} \mathrm{ha}^{-1}$, respectively, which are within the acceptable limits for soil loss proposed by the FAO (1967). Although the total annual soil loss was similar to previously reported values (AGUIAR et al., 2006; ALBUQUERQUE et al., 2002; MARTIN et al., 2003; RODRIGUES, 2009; SANTOS, 2009), these data were measured in different parts of Brazil, and there was a high variation in the coefficient value $(\mathrm{CV})$ between months. This high $\mathrm{CV}$, which was expected, was attributed to the high spatial and temporal variability of rainfall throughout the year. This indicates that information on annual soil loss should be investigated carefully because processes are not precisely represented.

Although the majority of rainfall and erosivity events occurred in April (FIG. 3), the largest values of $\mathrm{I}_{30}$ (the maximum 30-min intensity) and $\mathrm{EI}_{30}$ (rainfall erosivity index for storms) were recorded in February. The absolute highest values of $\mathrm{I}_{30}$ and $\mathrm{EI}_{30}$ were observed on February $18^{\text {th }}$ and measured $76.7 \mathrm{~mm} \mathrm{~h}^{-1}$ and 936.5 $\mathrm{MJ} \mathrm{mm} \mathrm{ha}^{-1} \mathrm{~h}^{-1}$, respectively, and the highest value of rainfall occurred on January $22^{\text {nd }}$, indicating that the highest precipitation value does not necessarily generate the highest rainfall erosivity index.

During the study period, the greatest surface runoff values occurred in the February $18^{\text {th }}$ and April $15^{\text {th }}$ events, and the highest values of soil loss were registered in the February $12^{\text {th }}$ and February $18^{\text {th }}$ events (FIG. 4). Losses prior to April $15^{\text {th }}$ were highly correlated with runoff depth, indicating that surface runoff was the dominant factor. After April $17^{\text {th }}$, soil losses were independent of runoff depth because the quantity of soil loss was stable at different values of runoff. These observations could be attributed to factors such as rainfall intensity, vegetation coverage and antecedent soil moisture (MARTINS et al., 2003).

Based on the events on March $3^{\text {rd }}$ and $4^{\text {th }}$, strong relationships were observed between soil loss and the maximum 30-min intensity $\left(\mathrm{I}_{30}\right)$ and the maximum rainfall erosivity index $\left(\mathrm{EI}_{30 \max }\right)$. For the March $3^{\text {rd }}$ event, $\mathrm{I}_{30 \max }$ was $5.1 \mathrm{~mm} \mathrm{~h}^{-1}, \mathrm{EI}_{30}$ was $6.2 \mathrm{MJ} \mathrm{mm} \mathrm{ha}^{-1} \mathrm{~h}^{-1}$ and the total soil loss was $0.98 \mathrm{~kg} \mathrm{ha}^{-1}$. For the March $4^{\text {th }}$ event, $\mathrm{I}_{30 \max }$ was $29.6 \mathrm{~mm} \mathrm{~h}^{-1}$ (480\% greater than the previous event), $\mathrm{EI}_{30}$ was $121.4 \mathrm{MJ} \mathrm{mm} \mathrm{ha}^{-1} \mathrm{~h}^{-1}(1,856 \%$ greater than the previous event) and the total soil loss was $98.90 \mathrm{~kg} \mathrm{ha}^{-1}$, demonstrating the effects on soil loss of surface runoff and disaggregation and transport of soil particles following the impact of raindrops.

The soil loss for the March $18^{\text {th }}$ event, which had an $\mathrm{EI}_{30}$ of $177.5 \mathrm{MJ} \mathrm{mm} \mathrm{ha}^{-1} \mathrm{~h}^{-1}$ (FIG. 3) and a precipitation

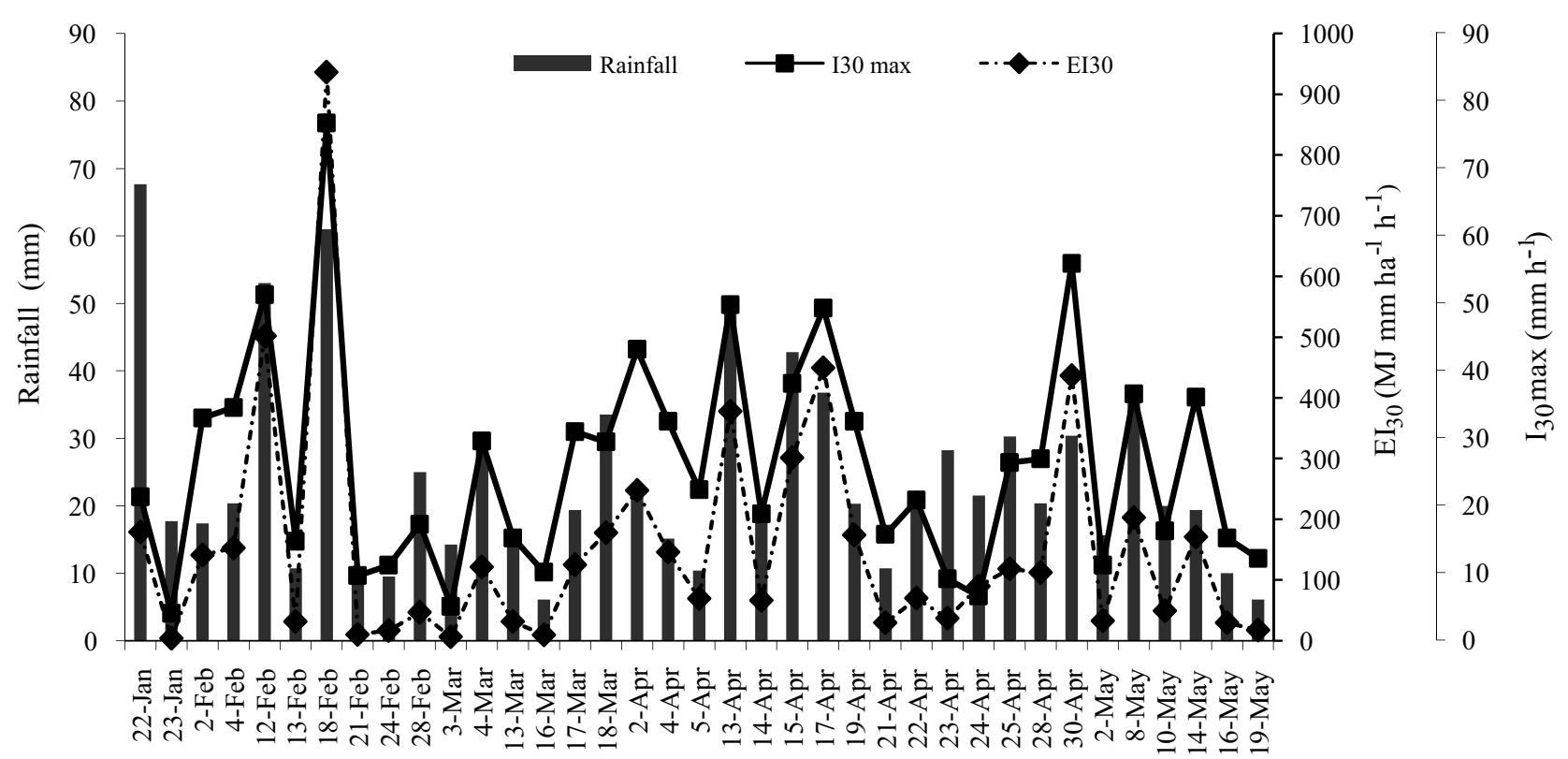

Figure 3 - Precipitation (PPT), maximum 30-min intensity $\left(\mathrm{I}_{30}\right)$ and rainfall erosivity index for storms $\left(\mathrm{EI}_{30}\right)$ in the experimental plot 


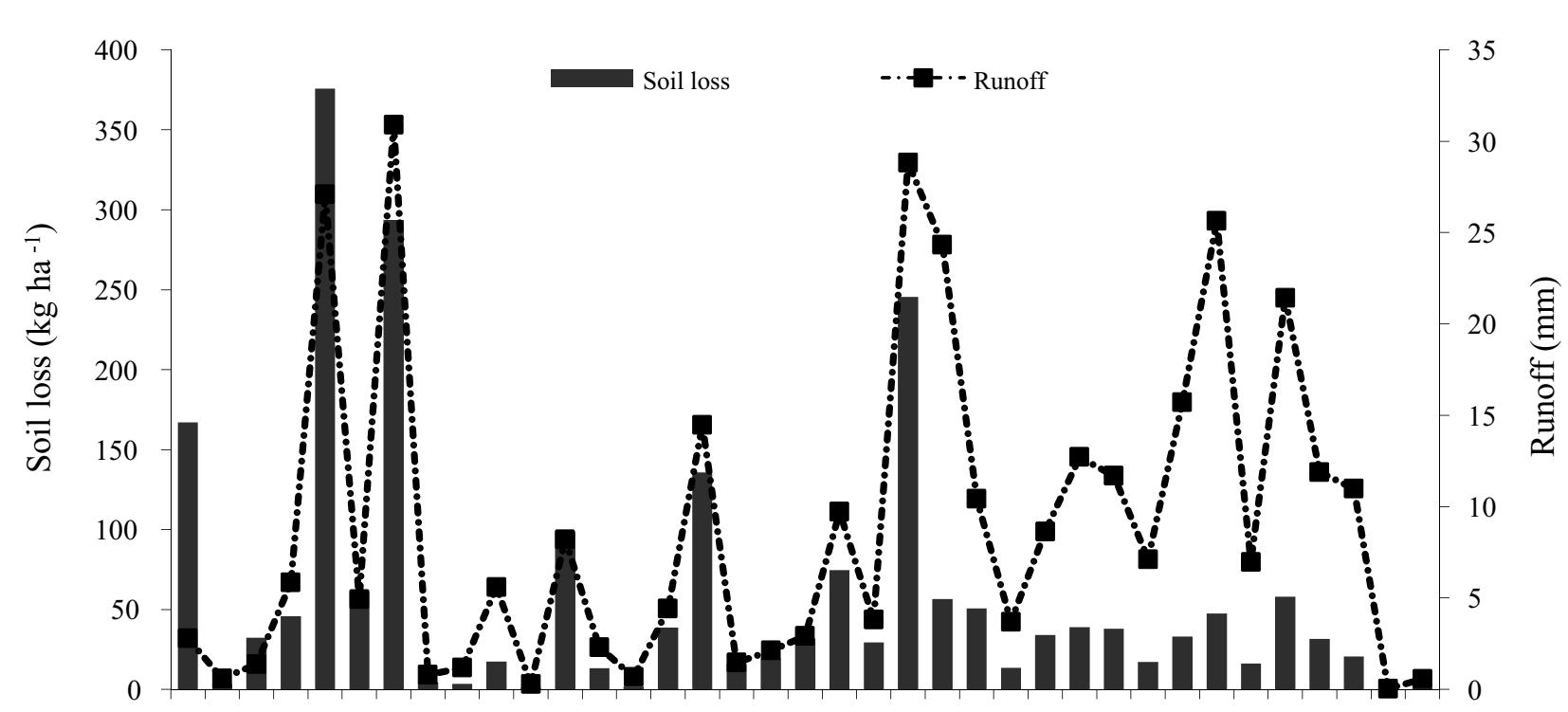

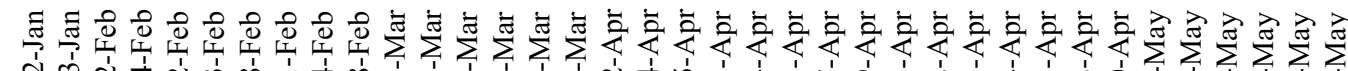

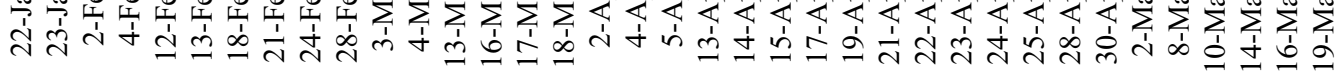

Figure 4 - Soil loss and runoff depth for each event

depth of $33.5 \mathrm{~mm}$ and followed 9 days of rain totaling 43 $\mathrm{mm}$, reached $135.7 \mathrm{~kg} \mathrm{ha}^{-1}$ (FIG. 3). For the subsequent April $2^{\text {nd }}$ event, which followed a fourteen-day dry spell and had a precipitation depth of $22.7 \mathrm{~mm}$ and an $\mathrm{EI}_{30}$ of $247.3 \mathrm{MJ} \mathrm{mm} \mathrm{ha}^{-1} \mathrm{~h}^{-1}$, the soil loss was $15.6 \mathrm{~kg} \mathrm{ha}^{-1}$. Although the number of studied events was small, the results demonstrated the effect of antecedent soil moisture. This could be partially explained by the soil classification (Vertisols Ebonics Carbonates), which showed clay of type 2:1. The rainfall that precedes a given event, which determines the antecedent soil moisture prior to subsequent rainfall events, is strongly related to soil loss (GUADAGNIN et al., 2005).

The influence of vegetation coverage was observed in the events of February $12^{\text {th }}$ and April $13^{\text {th }}$, which had similar rainfall depths and precipitation amounts during the 3 days before the events of 0 and $20.3 \mathrm{~mm}$, respectively. For the February $12^{\text {th }}$ event, $\mathrm{EI}_{30}$ was $501.77 \mathrm{MJ} \mathrm{mm} \mathrm{ha}^{-1} \mathrm{~h}^{-1}$, the total precipitation amount was $50.3 \mathrm{~mm}$ and the total soil loss was $375.83 \mathrm{~kg} \mathrm{ha}^{-1}$. For the April 13 ${ }^{\text {th }}$ event, which occurred two months after the development of coverage vegetation, $\mathrm{EI}_{30}$ was $377.68 \mathrm{MJ} \mathrm{mm} \mathrm{ha}^{-1} \mathrm{~h}^{-1}$, the total precipitation amount was $50.5 \mathrm{~mm}$ and the total soil loss was $74.49 \mathrm{~kg} \mathrm{ha}^{-1}$, which was $404.5 \%$ less than the amount from the February $12^{\text {th }}$ event and demonstrated the shielding effect of vegetation (DASS et al., 2011).

For the rainfall events of April $2^{\text {nd }}, 4^{\text {th }}$ and $5^{\text {th }}$, $\mathrm{EI}_{30} \mathrm{~s}$ were $247.32 ; 146.05$ and $69.56 \mathrm{MJ} \mathrm{mm} \mathrm{ha}^{-1} \mathrm{~h}^{-1}$
(FIG. 3), total precipitation amounts were 22.8; 15.1 and $10.4 \mathrm{~mm}$ and total soil losses were $15.63 ; 19.48$ and $31.75 \mathrm{~kg} \mathrm{ha}^{-1}$, respectively (FIG. 4). These trends were likely attributable to the progressive degradation and deposition of soil particles on the lower parts of the plot and their transport during the subsequent rainfall events, which had decreasing erosive energies. Among these three events, the April $2^{\text {nd }}$ event registered the highest rainfall depth and the highest maximum rainfall erosivity index, expressing the greater ability to disaggregate soil. Because this event occurred after 14 consecutive dry days, the soil moisture and surface runoff were low $(1.46 \mathrm{~mm})$, indicating a limited amount of available energy to transport soil that had been disaggregated by raindrops (ANGULOMARTÍNEZ; BEGUERÍA, 2009). For the subsequent events (April $4^{\text {th }}$ and $5^{\text {th }}$ ), rainfall depths and $\mathrm{EI}_{30}$ values were lower, but soil loss was higher because the soil had been disaggregated by previous events. Erosion is a complex process based on soil type and moisture, native vegetation, landscape properties, rainfall intensity and cumulative rainfall amounts (BAGARELLO; FERRO, 2004; CERDAN et al., 2010).

Calcium was the most leached nutrient in the runoff in a given month, with a maximum total amount of $47.33 \mathrm{~kg} \mathrm{ha}^{-1}$. The higher values for calcium could be explained by its high concentration in the soil, which was classified as Vertisols Ebonics Carbonates High concentrations of calcium in surface runoff have been found in others studies (LOBATO et al., 2009). 
Table 3 - Monthly and total losses of monitored nutrients

\begin{tabular}{|c|c|c|c|c|c|c|c|}
\hline \multirow{2}{*}{ Month } & Rainfall & Runoff & $\mathrm{Ca}$ & $\mathrm{Mg}$ & $\mathrm{K}$ & $\mathrm{PO}$ & SO \\
\hline & \multicolumn{2}{|c|}{------------(mm)------------ } & \multicolumn{5}{|c|}{ - } \\
\hline January & 193.3 & 3.4 & 0.062 & 0.009 & 0.059 & 0.004 & 0.153 \\
\hline February & 217.7 & 77.8 & 11.600 & 1.340 & 1.120 & 0.020 & 2.390 \\
\hline March & 134.4 & 30.4 & 4.583 & 0.437 & 0.307 & 0.021 & 0.937 \\
\hline April & 398.9 & 168.9 & 26.619 & 6.031 & 2.214 & 0.181 & 2.821 \\
\hline May & 118.3 & 51.9 & 4.462 & 0.886 & 2.145 & 0.005 & 0.699 \\
\hline Total & 1062.6 & 332.3 & 47.330 & 8.700 & 5.900 & 0.23 & 7.000 \\
\hline Total accumulated & 1062.6 & 332.3 & 68.96 & & & & \\
\hline
\end{tabular}

The losses of $\mathrm{K}$ were higher than those of $\mathrm{PO}$ because of the higher solubility of K (AGUIAR et al., 2006; BERTOL et al., 2004; SCHICH et al., 2000). The total loss of nutrients was $68.96 \mathrm{~kg} \mathrm{ha}^{-1}$, and the individual nutrients were lost in the following order: $\mathrm{Ca}>\mathrm{Mg}>\mathrm{SO}>\mathrm{K}>\mathrm{PO}$. Approximately $68.6 \%$ of the total loss of nutrients was attributable to calcium, which could be explained by the high concentration of calcium in the soil (LOBATO et al., 2009).

\section{Conclusions}

1. The data from this study, although preliminary, are important to the best definitions of land use planning and management, especially in the semiarid regions of Brazil where data on soil loss are scarce. The use of experimental plots facilitated a simplified understanding of individual processes and supported an understanding of the interaction of factors related to erosion;

2. Rainfall intensity, the erosivity index of storms, the antecedent soil moisture and cover vegetation are important factors in the erosion processes. The high variability of individual events is determined by the interactions of these factors, which express the dynamics of the processes;

3. The total soil loss in a plot in the Caatinga forest was $2,166.6 \mathrm{~kg} \mathrm{ha}^{-1}$, according to values reported by the FAO for shallow and impervious soils.

\section{Acknowledgements}

The financial support provided by the Conselho Nacional de Desenvolvimento Científico e Tecnológico (CNPq), Universidade Federal do Ceará and the Instituto
Federal de Educação, Ciência e Tecnologia do Ceará (IFCE) is gratefully acknowledged.

\section{References}

AGUIAR, M. I. et al. Perdas de solo, água e nutrientes em sistemas agroflorestais no município de Sobral, CE. Revista Ciência Agronômica, v. 37, n. 03, p. 270-278, 2006.

ALBUQUERQUE, A. W. et al. Manejo da cobertura do solo e de práticas conservacionistas nas perdas de solo e água em Sumé, PB. Revista Brasileira de Engenharia Agrícola e Ambiental, v. 06, n. 01, p.136-141, 2002.

ANGULO-MARTÍNEZ, M.; BEGUERÍA, S. Estimating rainfall erosivity from daily precipitation records: A comparison among methods using data from the Ebro Basin (NE Spain). Journal of Hydrology, v. 379, n. 01/02, p. 111-121, 2009.

AMERICAN PUBLIC HEALTH ASSOCIATION (APHA). Standard methods for the examination of water and wastewater. 20. ed. Washington, DC: American Public Health Association, 1998. $1220 \mathrm{p}$.

BAGARELLO, V., FERRO, V. Plot-scale measurement of soil erosion at the experimental area of Sparacia (southern Italy). Hydrological Processes, v. 18, n. 01, p. 141-157. 2004.

BERTOL, I. et al. Perdas de fósforo e potássio por erosão hídrica em um Inceptisol sob chuva natural. Revista Brasileira de Ciências do Solo, v. 28, p. 485-494, 2004.

BOIX-FAYOS, C. et al. Causes and underlying processes of measurement variability in field erosion plots in Mediterranean conditions. Earth Surface Processes and Landforms, v. 32, p. 85-101, 2007.

CERDAN, O. et al. Rates and spatial variations of soil erosion in Europe: A study based on erosion plot data. Geomorphology, v. 122, n. 01/02, p. 167-177, 2010.

DASS, A. et al. Runoff capture through vegetative barriers and planting methodologies to reduce erosion, and improve 
soil moisture, fertility and crop productivity in southern Orissa, India. Nutrient Cycling in Agroecosystems, v. 89, n. 01, p.45-57, 2011.

EMPRESA BRASILEIRA DE PESQUISA AGROPECUÁRIA (EMBRAPA). Sistema brasileiro de classificação de solos. Brasilia: EMBRAPA-CNPS, 1999. 412 p.

FOOD AND AGRICULTURE ORGANIZATION OF THE UNITED NATIONS (FAO). La erosion del suelo por El água: algunas medidas para combatirla en las tierras de cultivo. Roma, 1967. 207 p.

FOSTER, G. R. et al. Conservation of the Universal Soil Loss Equation the SI metric units. Journal of Soil and Water Conservation, v. 36, p. 355-359, 1981.

FRANCO, F. S. et al. Quantificação de erosão em Sistemas Agroflorestais e Convencionais na Zona da Mata de Minas Gerais. Revista Árvore, v. 26, n. 06, p. 751-760, 2002.

FUNDAÇÃO CEARENSE DE METEOROLOGIA E RECURSOS HÍDRICOS (FUNCEME). Séries pluviométricas do posto Iguatu - CE (1974 - 2008). Disponível em: $<$ http:// www.funceme.br/>. Acesso em: 20 jul. 2009.

GUADAGNIN, J. C. et al. Perdas de solo, água e nitrogênio por erosão hídrica em diferentes sistemas de manejo. Revista Brasileira de Ciência do Solo, v. 29, p. 277-286, 2005.

FUNDAÇÃO INSTITUTO BRASILEIRO DE GEOGRAFIA E ESTATÍSTICA (IBGE). Censos Demográficos. Disponivel em: http://www.ibge.gov.br/home/estatística/população/censo2007/ principal.shtm. Acesso em:19 de agosto 2010.

INÁCIO, E. S. B. et al. Erosão hídrica em agrofloresta no Sul da Bahia. Bahia Agrícola, v. 7, n. 01, p. 75-78, 2005.

LOBATO, F. A. O. et al. Perdas de solo e nutrientes em área de Caatinga decorrente de diferentes alturas pluviométricas. Revista Agroambiente, v. 03, n. 02, p. 65-71. 2009.
MARTINS, S. G. et al. Perdas de solo e água por erosão hídrica em sistemas florestais na região de Aracruz (ES). Revista Brasileira de Ciências do Solo, v. 27, n. 03, p. 395403. 2003.

MELLO, E. L. et al. Perdas de solo e água em diferentes sistemas de manejo de um nitossolo háplico submetido à chuva simulada. Revista Brasileira de Ciências do Solo, v. 27, n. 05, p. 901-909, 2003.

RODRIGUES, J. O. O uso da terra e a resposta hidrossedimentológica em pequenas bacias hidrográficas semiáridas. 2009. 128 f. Dissertação (Mestrado em Engenharia Agrícola - Manejo e Conservação de Bacias Hidrográficas no Semiárido) - Universidade Federal do Ceará, Fortaleza.

SANTOS, C. A. G. et al. Análise das perdas de água e solo em diferentes coberturas superficiais no semi-árido da Paraíba. Revista OKARA: Geografia em debate, v. 01, n. 01, p. 1-152. 2007.

SANTOS, C. A. G. et al. Influência do tipo da cobertura vegetal sobre a erosão no semi-árido paraibano. Revista Brasileira de Engenharia Agrícola e Ambiental, v. 04, n. 01, p. 92-96, 2000.

SANTOS, J. C. N. Erosão laminar em microbacia com cobertura herbácea no semi-árido cearense. 2009. $71 \mathrm{f}$. Monografia (Graduação em Tecnologia em Irrigação e Drenagem) - Instituto Federal de Educação, Ciência e Tecnologia do Ceará - Campus Iguatu, Iguatu.

SCHICK, J. et al. Erosão hídrica em Cambissolo húmico alumínico submetido a diferentes sistemas de preparo e cultivo do solo: I. Perdas de solo e água. Revista Brasileira de Ciências do Solo, v. 24, n. 02, p. 427-436, 2000.

WISCHMEIER, W. H.; SMITH, D. D. Predicting rainfall erosion losses: A guide to conservation planning. Washington: USDA, 1978. $58 \mathrm{p}$. 